\title{
Experimental and modeling study of high performance direct carbon solid oxide fuel cell with in situ catalytic steam-carbon gasification reaction \\ Haoran $\mathrm{Xu}^{1,2}$, Bin Chen ${ }^{1}$, Houcheng Zhang ${ }^{1,3}$, Peng Tan ${ }^{1}$, Guangming Yang ${ }^{4}$, John T.S. Irvine ${ }^{2 *}$, Meng $\mathrm{Ni}^{1,5^{*}}$ \\ ${ }^{1}$ Building Energy Research Group, Department of Building and Real Estate The Hong Kong Polytechnic University, Hung Hom, Kowloon, Hong Kong, China \\ ${ }^{2}$ School of Chemistry, University of St Andrews, St Andrews, Fife, KY16 9ST, UK \\ ${ }^{3}$ Department of Microelectronic Science and Engineering, Ningbo University, Ningbo 315211, China \\ ${ }^{4}$ Jiangsu National Synergetic Innovation Center for Advanced Materials (SICAM), College of Chemical Engineering, Nanjing Tech University, No.5 Xin Mofan Road, Nanjing 210009, P.R. China \\ ${ }^{5}$ Environmental Energy Research Group, Research Institute for Sustainable Urban Development (RISUD), The Hong Kong Polytechnic University, Hung Hom, Kowloon, Hong Kong, China
}

\section{Abstract:}

In this paper, 2D models for direct carbon solid oxide fuel cells (DC-SOFCs) with in situ catalytic steam-carbon gasification reaction are developed. The simulation results are found to be in good agreement with experimental data. The performance of DC-SOFCs with and without catalyst are compared at different operating potential, anode inlet gas flow rate and operating temperature. It is found that adding suitable catalyst can significantly speed up the in situ steam-carbon gasification reaction and improve the performance of DC-SOFC with $\mathrm{H}_{2} \mathrm{O}$ as gasification agent. The potential of syngas and electricity co-generation from the fuel cell is also evaluated, where the composition of $\mathrm{H}_{2}$ and $\mathrm{CO}$ in syngas can be adjusted by controlling the anode inlet gas flow rate. In addition, the performance DC-SOFCs and the percentage of fuel in the outlet gas are both increased with increasing operating temperature. At a reduced temperature (below $800^{\circ} \mathrm{C}$ ), good performance of DC-SOFC can still be obtained with in-situ 
catalytic carbon gasification by steam. The results of this study form a solid foundation to understand the important effect of catalyst and related operating conditions on $\mathrm{H}_{2} \mathrm{O}$-assisted DC-SOFCs.

Keywords: Fuel cell; carbon gasification; syngas generation

* Corresponding authors:

Email: bsmengni@polyu.edu.hk; Tel: 852-27664152; Fax: 852-27645131 (NI M).

Email: jtsi@st-andrews.ac.uk; Tel: 01334463817 (Irvine JTS) 


\section{Introduction}

With the increasing global attention on energy crisis and related environmental problems such as global warming and air pollution, clean utilization of energy and high efficiency energy conversion devices have received great interest from all over the world. Apart from developing renewable energy technologies, the clean and efficient utilization of fossil fuels remains to be an important topic as fossil fuels will continue to be the dominating energy source in the coming decades.

Solid oxide fuel cell (SOFC) is one of the most attractive clean and high efficient energy conversion devices for electricity power generation [1-5]. SOFCs are all solid-state devices with sandwiched structure working at high temperature (e.g. $\left.800{ }^{\circ} \mathrm{C}\right)$. Its sandwiched structure includes two porous electrodes for electrochemical reactions with a dense electrolyte between them for gas separation and $\mathrm{O}^{2-}$ ions transportation. The electrochemical reaction between fuels (e.g. $\mathrm{H}_{2}$ ) and oxidants in electrodes ensures the high energy conversion efficiency. The postprocess of emission gases is also relatively easy as they are separated by the dense electrolyte. To achieve a lower operational cost and higher volumetric energy density, the direct utilization of solid carbon in SOFCs (called as direct carbon solid oxide fuel cells, DC-SOFCs) has received rising interest [6-9]. In DC-SOFCs, solid carbon is placed in the anode chamber and chemically oxidized by an agent gas (e.g. $\mathrm{CO}_{2}$ ) to form gaseous fuel (e.g. CO). The produced gaseous fuel then diffuses to the anode triple phase boundary (TPB) sites for electrochemical oxidization and regenerates the agent gas. This so-called "CO shuttle mechanism" ensures the 
process to take place continuously as long as there is enough solid carbon for gasification.

The gasification reaction between solid carbon and $\mathrm{CO}_{2}$ is called reversible Boudouard reaction, which is a key reaction affecting the performance of DC-SOFC. As reported by Wu et al.[10], adopting $\mathrm{Fe}_{\mathrm{m}} \mathrm{O}_{\mathrm{n}}$-alkaline metal oxide catalyst greatly enhanced $\mathrm{CO}$ formation rate in graphite (e.g. 19 times improvement at $800{ }^{\circ} \mathrm{C}$ ) and activated carbon (e.g. 6 to 155 times improvement at $800{ }^{\circ} \mathrm{C}$ depending on the surface area). Benefited from the largely enhanced Boudouard reaction, they successfully obtained a peak power density of $286 \mathrm{~mW} \mathrm{~cm}{ }^{-2}$ at $1123 \mathrm{~K}$ even without external $\mathrm{CO}_{2}$ feeding. Similarly, Tang et al. [11] significantly improved the performance of DC-SOFC (10 times higher output power density at 1073K) by loading Febased catalyst on the carbon fuel. Considering the importance of catalyst for Boudouard reaction in DC-SOFCs, $\mathrm{Li}$ et al.[12] compared $\mathrm{Ni}, \mathrm{K}$ and $\mathrm{Ca}$ additives in carbon black and found that the catalytic effects were: $\mathrm{K}>\mathrm{Ni}>\mathrm{Ca}$. Borja et al. [13] further studied the synergistic effect of the carbonate catalysts and Li-K carbonate system displayed the highest power densities compared with $\mathrm{Li}-\mathrm{Na}, \mathrm{Li}-\mathrm{Na}-\mathrm{K}, \mathrm{Li}-\mathrm{Ba}$ and $\mathrm{Na}-\mathrm{K}$ carbonate mixtures. Apart from the use of catalysts, the carbon structure also affect the Boudouard reaction rate. Jiao et al. [14] treated coal char with alkali for structure modification to enlarge its specific surface. The output power density of DC-SOFCs was increased significantly from $62 \mathrm{~mW} \mathrm{~cm}^{-2}$ to $220 \mathrm{~mW}$ $\mathrm{cm}^{-2}$ at $1123 \mathrm{~K}$. In addition, some researchers recently proposed using $\mathrm{H}_{2} \mathrm{O}$ instead of $\mathrm{CO}_{2}$ as agent for carbon gasification. Ong and Ghoniem [15] developed a 1D model to compare $\mathrm{H}_{2} \mathrm{O}$ and $\mathrm{CO}_{2}$ as gasification agent for the indirect carbon fuel cell. The performance of the carbon 
fuel cell with external carbon gasification was improved by 3-5 times with $\mathrm{H}_{2} \mathrm{O}$ recycling from anode to the gasifier instead of $\mathrm{CO}_{2}$ between $700{ }^{\circ} \mathrm{C}$ and $800^{\circ} \mathrm{C}$. In the indirect carbon SOFC, the carbon gasifier needs significant amount of heat input while the heat generated from SOFC is not well utilized. For comparison, the generated heat in the SOFC can be easily used by the carbon gasification reaction in a DC-SOFC, which could improve the overall energy efficiency of the energy efficiency of the carbon-based SOFC system. More recently, experimental and modeling works on DC-SOFC with internal carbon gasification by $\mathrm{CO}_{2}$ and $\mathrm{H}_{2} \mathrm{O}$ were conducted by Xu et al. [16]. Benefited from a much faster carbon gasification rate with $\mathrm{H}_{2} \mathrm{O}$ as agent, a significant improvement of peak power density was found from $158 \mathrm{~mW} \mathrm{~cm}^{-2}$ (with $\mathrm{CO}_{2}$ as agent) to $385 \mathrm{~mW} \mathrm{~cm}^{-2}$ (with $\mathrm{H}_{2} \mathrm{O}$ as agent) at $1123 \mathrm{~K}$. Besides, using $\mathrm{H}_{2} \mathrm{O}$ as a gasification agent offers DC-SOFC the potential for syngas and electrical power co-generation. As the syngas ( $\mathrm{CO}$ and $\mathrm{H}_{2}$ mixture) is an important raw material for fuel and chemical industries, sometimes both electricity and syngas are needed simultaneously. Thus, users can control the operating condition of a single device to obtain their preferred product. Although the benefits brought by using $\mathrm{H}_{2} \mathrm{O}$ as DC-SOFC agent have been demonstrated, no study about in situ catalytic steam-carbon gasification in DC-SOFCs has been reported yet. According to Kopyscinski et al. [17], suitable catalysts like $\mathrm{K}_{2} \mathrm{CO}_{3}$ could hopefully increase the steamcarbon gasification rate. Although extra cost is needed for catalytic fuel pre-processing, adding catalyst is still a very attractive strategy for direct carbon SOFCs as not only a higher power density can be expected due to faster steam-carbon gasification rate, but also higher fuel 
concentration at the anode outlet can be obtained for wider applications such as fuel and electricity co-generation. Therefore, there is a need to systematically investigate the improvement brought by in situ catalytic steam-carbon gasification in DC-SOFCs.

In order to fill the research gap mentioned-above, both experimental and numerical studies are conducted for DC-SOFCs with in situ catalytic steam-carbon gasification reaction. Experimental I-V curves and detailed numerical simulations are carried out in this paper to evaluate the catalyst effect and the potential of the DC-SOFC for electricity and fuel cogeneration. The models are validated by comparing the simulation results with experimental data and good agreement is observed.

\section{Model description}

The chemical/electrochemical reaction, ion/electron conduction and mass/momentum transportation are fully coupled in the 2D mathematical DC-SOFC models. The schematics of DC-SOFC using $\mathrm{H}_{2} \mathrm{O}$ as agent is shown in Fig.1. Solid carbon is placed in the anode chamber (near the porous anode) and $\mathrm{H}_{2} \mathrm{O}$ is supplied from the anode inlet for steam-carbon gasification. The button cell has a surface area of $0.45 \mathrm{~cm}^{2}$ with the thickness of its anode, electrolyte and cathode being $400 \mu \mathrm{m}, 8 \mu \mathrm{m}$ and $24 \mu \mathrm{m}$, respectively. The cell uses Ni-YSZ (yttrium stabilized zirconium) composites as anode, bilayer YSZ/SDC (samaria-doped ceria) as electrolyte and LSCF (lanthanum strontium cobalt ferrite) as cathode. Material properties, chemical/electrochemical reaction and other tuning parameters are adopted and listed in Table 1 (ref. [18-22]) and Table 2, respectively. 


\subsection{Model assumption}

(1) Both $\mathrm{H}_{2}$ and $\mathrm{CO}$ participate in the electrochemical reactions and the TPB sites they shared is proportional to their local concentration percentage.

(2) TPB sites are distributed uniformly in the whole porous electrode. Both ionic- and electronic- conducting phases in the porous electrodes are homogeneous and continuous.

(3) Gases in the model $\left(\mathrm{CO}, \mathrm{H}_{2} \mathrm{O}, \mathrm{H}_{2}, \mathrm{O}_{2}, \mathrm{~N}_{2}\right)$ are ideal gases.

(4) Temperature distribution in the cell is uniform due to its small size.

(5) The volume of carbon fuel in the anode chamber does not change with time.

\subsection{Chemical reactions}

In anode chamber, the key chemical reaction (Eq. (1)) in the DC-SOFC is steam-carbon gasification, which converts solid carbon into gas fuels $\left(\mathrm{H}_{2}\right.$ and $\left.\mathrm{CO}\right)$. Its reaction rate can be calculated by Eq. (2)[23]. Different tuning parameters (listed in Table 2) are used when catalyst is adopted for the reaction.

$\mathrm{C}+\mathrm{H}_{2} \mathrm{O} \leftrightarrow \mathrm{CO}+\mathrm{H}_{2}$

$R_{C_{-} H 2 O}=\frac{K_{1} p_{H_{2} O}}{1+K_{2} p_{H_{2}}+K_{3} p_{H_{2} O}}$

As $\mathrm{CO}_{2}$ is formed in the electrochemical oxidation of $\mathrm{CO}$, the Boudouard reaction (Eq. (3)) is also considered. Its reaction rate can be calculated by Eq. (4)[23].

$\mathrm{C}+\mathrm{CO}_{2} \leftrightarrow 2 \mathrm{CO}$

$R_{C_{-} \mathrm{CO} 2}=\frac{K_{4} p_{\mathrm{CO}_{2}}}{1+K_{5} p_{\mathrm{CO}+K_{6}} p_{\mathrm{CO}_{2}}}$

Due to the co-existence of $\mathrm{H}_{2} \mathrm{O}$ and $\mathrm{CO}$, water gas shift reaction (WGSR) catalyzed by nickel 
in porous electrode is also considered as shown in Eq. (5). Its reaction rate can be calculated by Eqs. (6-9).[24]

$\mathrm{CO}+\mathrm{H}_{2} \mathrm{O} \leftrightarrow \mathrm{CO}_{2}+\mathrm{H}_{2}$

$R_{W G S R}=k_{S f}\left(p_{\mathrm{H}_{2} \mathrm{O}} p_{\mathrm{CO}}-\frac{p_{\mathrm{H}_{2}} p_{\mathrm{CO}_{2}}}{K_{p s}}\right)$

$k_{s f}=0.0171 \exp \left(\frac{-103191}{R T}\right)\left(\mathrm{mol} \mathrm{m} \mathrm{m}^{-3} \mathrm{~Pa}^{-2} \mathrm{~s}^{-1}\right)$

$K_{p s}=\exp \left(-0.2935 Z^{3}+0.6351 Z^{2}+4.1788 Z+0.3169\right)$

$Z=\frac{1000}{T}-1(9)$

\subsection{Electrochemical reaction}

Both $\mathrm{H}_{2}$ and $\mathrm{CO}$ produced in the chamber will transport to anode TPB sites where they electrochemically react with $\mathrm{O}^{2-}$ and release electrons as shown in Eq. (10) and Eq. (11). The $\mathrm{O}^{2-}$ ions transport through the electrolyte from the cathode, where the $\mathrm{O}_{2}$ molecules are reduced as shown in Eq. (12).

$$
\begin{aligned}
& \mathrm{H}_{2}+\mathrm{O}^{2-} \rightarrow \mathrm{H}_{2} \mathrm{O}+2 e^{-} \\
& \mathrm{CO}+\mathrm{O}^{2-} \rightarrow \mathrm{CO}_{2}+2 e^{-} \\
& \mathrm{O}_{2}+4 e^{-} \rightarrow 2 \mathrm{O}^{2-}
\end{aligned}
$$

Based on the above equations, respective equilibrium potentials $\left(E_{e q}\right)$ for $\mathrm{H}_{2}$ and $\mathrm{CO}$ as fuel can be calculated as Eq. (13) and Eq. (14)

$$
\begin{aligned}
& E_{C O}=E_{C O}^{0}+\frac{R T}{2 F} \ln \left[\frac{P_{C O}^{L}\left(P_{O_{2}}^{L}\right)^{1 / 2}}{P_{C O_{2}}^{L}}\right] \\
& E_{H_{2}}=E_{H_{2}}^{0}+\frac{R T}{2 F} \ln \left[\frac{P_{H_{2}}^{L}\left(P_{O_{2}}^{L}\right)^{1 / 2}}{P_{H_{2} O}^{L}}\right]
\end{aligned}
$$

Here $E^{0}$ is the standard potential $(\mathrm{V}), \mathrm{R}$ is the universal gas constant $\left(8.3145 \mathrm{~J} \mathrm{~mol}^{-1} \mathrm{~K}^{-1}\right)$, T is 
the operating temperature $(\mathrm{K}), \mathrm{F}$ is the Faraday constant $\left(96485 \mathrm{C} \mathrm{mol}^{-1}\right) . \quad P^{L}$ is the local gas partial pressure (Pa). The values of $E_{C O}^{0}$ and $E_{H_{2}}^{0}$ can be calculated by Eq. (15) and Eq. (16): $E_{C O}^{0}=1.46713-0.0004527 T(\mathrm{~V})$

$E_{H_{2}}^{0}=1.253-0.00024516 T(\mathrm{~V})$

It should be noted that the equilibrium potentials calculated by Eq. (13) and Eq. (14) are equal at an open circuit condition. When current is extracted from DC-SOFC, the equilibrium potentials for $\mathrm{H}_{2}$ fuel and $\mathrm{CO}$ fuel become different due to the different overpotential losses involved in electrochemical oxidation of $\mathrm{H}_{2}$ and $\mathrm{CO}$.

The operating potential $(V)$ can be calculated by equilibrium potential and operating overpotential losses (V) as shown in Eq. (17):

$V=E_{\text {eq }}-\eta_{\text {act }}-\eta_{\text {ohmic }}$

The operating overpotential loss includes activation overpotential loss $\left(\eta_{\text {act }}\right)$ and ohmic loss $\left(\eta_{\text {ohmic }}\right) . \eta_{\text {act }}$ reflects the potential barrier for the electrochemical reaction to overcome, which can be described by Butler-Volmer equation as shown in Eq. (17).

$i=i_{0}\left\{\exp \left(\frac{\alpha n F \eta_{a c t}}{R T}\right)-\exp \left(\frac{(1-\alpha) n F \eta_{a c t}}{R T}\right)\right\}$

where $i$ is the operating current density $\left(\mathrm{A} \mathrm{m}^{-2}\right), i_{0}$ is the exchange current density $\left(\mathrm{A} \mathrm{m}^{-2}\right)$, $\alpha$ is the electron transfer coefficient and $n$ is the number of transferred electrons per electrochemical reaction. Considering temperature effect, $i_{0}$ can be further expressed as Eq. (18).

$i_{0}=\gamma \exp \left(-\frac{E_{a c t}}{R T}\right)$ 
where $\gamma\left(\mathrm{A} \mathrm{m}^{-2}\right)$ is the pre-exponential factor and $E_{\text {act }}$ is the activation energy level $\left(\mathrm{J} \mathrm{mol}^{-1}\right)$. The ohmic overpotential $\left(\eta_{\text {ohmic }}\right)$ is related to the current intensity and ionic/electronic conductivity of the cell, and can be calculated by Ohm law. More detailed information can be found in our previous works [25-28].

\subsection{Mass and momentum transport}

Extended Fick's model is used to calculate the rate of mass transport $\left(N_{i}, \mathrm{~mol} \mathrm{~m}^{-3} \mathrm{~s}^{-1}\right)$ in channels and porous electrodes as shown in Eq. (19)[29]:

$N_{i}=-\frac{1}{R T}\left(\frac{B_{0} y_{i} P}{\mu} \frac{\partial \mathrm{P}}{\partial \mathrm{z}}-D_{i}^{\text {eff }} \frac{\partial\left(y_{i} \mathrm{P}\right)}{\partial \mathrm{z}}\right)(i=1, \ldots, n)$

where $B_{0}$ is the permeability $\left(\mathrm{m}^{2}\right)$ of the porous electrodes, $y_{i}$ is the mole fraction of component $i, \mu$ is the gas viscosity $\left(\mathrm{N} \mathrm{m}^{-1} \mathrm{~s}^{-1}\right)$ and $D_{i}^{\text {eff }}$ is the overall effective diffusion coefficient $\left(\mathrm{m}^{2} \mathrm{~s}^{-1}\right)$ of component $i$ in the porous electrodes, which can be calculated by Eq. (20) [30]:

$D_{i}^{e f f}=\frac{\varepsilon}{\tau}\left(\frac{1}{D_{i m}^{e f f}}+\frac{1}{D_{i k}^{e f f}}\right)^{-1}$

where $\varepsilon$ is the porosity, $\tau$ is the tortuosity factor, $D_{i k}^{\text {eff }}$ and $D_{i m}^{e f f}$ are Knudsen diffusion coefficient $\left(\mathrm{m}^{2} \mathrm{~s}^{-1}\right)$ and molecular diffusion coefficient $\left(\mathrm{m}^{2} \mathrm{~s}^{-1}\right)$, respectively. Detailed calculation of $D_{i m}^{e f f}$ and $D_{i k}^{e f f}$ can be found in ref. [31]. It should also be noted that the Knudsen diffusion mechanism is neglected in the gas channels as the channel size is considerably larger than the mean-free path of the molecular species.

Navier-Stokes (N-S) equation including the Darcy's term is used to describe the momentum transport of gas species in porous electrodes as shown in Eq. (21): 
$\rho \frac{\partial u}{\partial t}+\rho u \nabla u=-\nabla p+\nabla\left[\mu\left(\nabla u+(\nabla u)^{T}\right)-\frac{2}{3} \mu \nabla u\right]-\frac{\varepsilon \mu u}{k}$

where $\rho\left(\mathrm{kg} \mathrm{m}^{-3}\right)$ is the gas density and $\mathrm{u}\left(\mathrm{m} \mathrm{s}^{-1}\right)$ is the velocity vector. When the last term on the right side is neglected, Eq. (20) is reduced to conventional N-S equation for momentum conservation in gas channels.

\subsection{Model solution}

Electric potentials are specified at the two electrodes while two ends of the cell are electrically insulated. Inflow gas mole fraction and flow rate (SCCM) are given at the inlets. The outflow condition is specified at the outlets of the gas channels. Zero flux is specified at the end of the electrodes and pressure condition is specified at the outlets of the two gas channels.

The model is solved at given operating conditions such as electric potentials, temperature, inlet gas flow rate and mole fraction. The output of the model includes distributions of the electrochemical reaction rates, chemical reaction rates and mole fraction of gas species in the cell. The commercial software COMSOL MULTIPHYSICS ${ }^{\circledR}$ is employed for the numerical simulation.

\section{Results and discussion}

\subsection{Experiments for model validation}

The fuel cell adopted in this study for model validation employed Ni-YSZ as anode supporting the bilayer YSZ/SDC electrolyte and LSCF cathode. $\mathrm{Na}_{2} \mathrm{CO}_{3}$ was adopted as the catalyst to enhance the steam-carbon gasification reaction. For a typical synthesis, 0.015 mole catalyst was dissolved into $30 \mathrm{ml}$ de-ionized water. Then 1 mole activated carbon was added to the 
solution under vigorous stirring for 12 hours. The colloid was dried at $110{ }^{\circ} \mathrm{C}$ for 4 hours and then calcined at $500{ }^{\circ} \mathrm{C}$ in nitrogen for 2 hours. It should be noted that the present study is the first attempt to improve the performance of DC-SOFC by in-situ catalytic steam-gasification of carbon. The focus is to demonstrate the effect of catalyst on power generation and syngas co-generation. The lab-scale impregnation method for catalyst addition to carbon fuel ensures good contact between the carbon particles and the catalyst, which could facilitate carbon gasification and is beneficial to DC-SOFC. However, the impregnation method may not be practical for large-scale applications due to the relatively high cost. For practical applications, industrial scale carbon/coal gasification technology should be adopted. For example, physical mixing in a fluidized bed offers a simple and low cost option and can be employed for largescale applications.

For the fuel cell test, the bottom cell was sealed onto a quartz tube by silver paste. The anode and cathode surfaces were printed with silver layers for current collection. $0.2 \mathrm{~g}$ solid carbon was fixed by asbestos in the anode chamber. A quartz tube was positioned beneath the carbon layer for introducing steam. The inlet gas flow rate of anode was set as 90 SCCM (standard conditions). $30 \mathrm{SCCM} \mathrm{H}_{2} \mathrm{O}$ was carried into anode by $60 \mathrm{SCCM} \mathrm{N}_{2}$ in the test. The operating temperature was kept constant at $850{ }^{\circ} \mathrm{C}$ during the test. Current-voltage values were collected based on the four-terminal configuration. The schematic designs for fuel cell tests could be found in ref. [10].

The modeling results of current-voltage characteristics for DC-SOFCs using $\mathrm{H}_{2} \mathrm{O}$ as agent are 
compared with experimental data as shown in Fig. 2. The quite small difference between the modeling results and experimental data validates the present model. The same structure and tuning parameters are used in the subsequent parametric simulations. It should be mentioned that the activated carbon is use in the experiments for model validation. When other types of carbon are used, the carbon gasification reaction kinetics could be different due to the different properties of carbon fuels. However, the proposed model can be easily applied to DC-SOFC with different types of carbon fuels by modifying the carbon oxidation reaction kinetics.

\subsection{Effect of applied voltage}

The voltage-current density-power density curves of DC-SOFCs using $\mathrm{H}_{2} \mathrm{O}$ as agent are shown in Fig. 3. The detailed operating conditions are listed in Table 3.

As can be seen in Fig. 3, the cell with in situ catalytic steam-carbon gasification has a much better performance compared with the cell without catalyst. By adding catalyst, the peak power density of the cell increases from about $3000 \mathrm{~W} \mathrm{~m}^{-2}$ to $4600 \mathrm{~W} \mathrm{~m}^{-2}$, with the maximum current density increasing from about $10000 \mathrm{~A} \mathrm{~m}^{-2}$ to $23000 \mathrm{~A} \mathrm{~m}^{-2}$. This significant performance improvement is mainly caused by the faster steam-carbon gasification kinetics. As can be seen in Fig. 4(a) and Fig. 4(b), the peak steam-carbon gasification reaction rate increases from 11.1 $\mathrm{mol} \mathrm{m} \mathrm{s}^{-3} \mathrm{~s}^{-1}$ to $292 \mathrm{~mol} \mathrm{~m}^{-3} \mathrm{~s}^{-1}$ with most parts in catalytic carbon layer being larger than $50 \mathrm{~mol}$ $\mathrm{m}^{-3} \mathrm{~s}^{-1}$. Consequently, the mole fraction of the fuel (both $\mathrm{H}_{2}$ and $\mathrm{CO}$ ) in anode is significantly improved from about 0.1 to about 0.4 as shown in Fig. 4(c) and Fig. 4(d). The high fuel concentration indicates the potential for syngas and electricity co-generation in DC-SOFC with 
in situ catalytic gasification.

It should also be noted that the fuel concentration distribution in anode is significantly affected by both steam-carbon gasification reaction and applied voltage. As can be found in Fig.5(a), the $\mathrm{H}_{2}$ mole fraction obtains a sharp increase to 0.4 in carbon layer at $0.9 \mathrm{~V}$ applied voltage, while it decreases quickly to 0.2 in the area close to anode at $0.1 \mathrm{~V}$ applied voltage. The relationship between electrochemical performance and syngas molar fraction on the anode surface is further shown in Fig. 5(b). The syngas molar fraction exceeds $80 \%$ at small operating current density but decreases to be less than $50 \%$ at a current density of $23000 \mathrm{~A} \mathrm{~m}^{-2}$. Thus, a high operating potential is more favored to maintain a high fuel concentration in the anode outlet gas.

\subsection{Effect of anode inlet gas flow rate}

In DC-SOFCs using $\mathrm{H}_{2} \mathrm{O}$ as agent, steam is introduced to the anode inlet as it participates in the carbon gasification reaction, however, the inlet steam can dilute fuel concentration on the other hand. Thus, it should be careful to choose a suitable steam flow rate in operation. For the study of anode inlet gas flow rate effect, the operating parameters are listed in Table 4.

As can be seen in Fig. 6, the performance of the fuel cell increases first at small anode gas flow rate, while decreases quickly at large flow rate. A small steam flow rate is more suitable for the fuel cell as it reaches the peak current density at 10 SCCM in this case. However, no significant decrease of current density is observed in a wide flow rate range when catalyst is added in the 
fuel cell. Besides, a large steam flow rate is more favored under the fast in situ catalytic gasification reaction with its peak current density being obtained at 40 SCCM flow rate.

In addition, the mole fraction of $\mathrm{H}_{2}$ and $\mathrm{CO}$ in anode is also significantly affected by inlet steam flow rate as can be seen in Fig. 7(a). Apart from different electrochemical reaction kinetics, the reaction rate of WGSR is another key factor to the mole fraction change of $\mathrm{H}_{2}$ and $\mathrm{CO}$ (as shown in Fig. 7(b)) since steam-carbon gasification produces equal amount of $\mathrm{H}_{2}$ and CO. At small gas flow rates, more $\mathrm{H}_{2}$ than $\mathrm{CO}$ is consumed by electrochemical reaction due to the faster reaction kinetics of $\mathrm{H}_{2}$, in the meanwhile, the lack of steam favors WGSR to convert $\mathrm{H}_{2}$ and $\mathrm{CO}_{2}$ into $\mathrm{H}_{2} \mathrm{O}$ and $\mathrm{CO}$ in anode (shown as negative value of WGSR in Fig. 7(b)). As a result, more $\mathrm{CO}$ than $\mathrm{H}_{2}$ is left in anode. With an increase of steam flow rate, the WGSR rate turns to positive and keeps growing, while the Boudouard reaction rate remains at a small value. Consequently, the mole fraction of $\mathrm{CO}$ keeps decreasing, while the mole fraction of $\mathrm{H}_{2}$ keeps rising to exceed $\mathrm{CO}$ and remains at a relative high level. This phenomenon indicates that the outlet gas composition from anode can be adjusted by controlling the inlet gas flow rate.

\subsection{Effect of operating temperature}

The operating temperature affects not only the electrochemical kinetics but also the chemical reaction rate, thus, both the output power and the fuel percentage $\left(\mathrm{H}_{2} \& \mathrm{CO}\right)$ in outlet gas will be significantly changed at different operating temperature. For the study of temperature effect, the operating parameters are listed in Table 5. 
As can be seen in Fig. 8(a), the current density of DC-SOFC with $\mathrm{H}_{2} \mathrm{O}$ as agent is increased at a higher temperature. The existence of catalyst improves the performance of DC-SOFC especially at a low operating temperature, where a large improvement can be found (4 times improvement at $923 \mathrm{~K}$ and 1.4 times improvement at $1173 \mathrm{~K}$ ). Although the output electricity power improvement by adding catalyst is not that significant at high operating temperature, the fuel percentage in outlet gas is largely improved as shown in Fig. 8(b). Benefited from faster chemical reaction kinetics as a higher temperature, the fuel percentage in outlet gas increases from $0.15 \%$ at $923 \mathrm{~K}$ to $20 \%$ at $1173 \mathrm{~K}$ without catalyst, while a percentage of $85 \%$ of fuel in the outlet gas can be obtained with the help of catalyst at $1173 \mathrm{~K}$. The high fuel concentration indicates an excellent potential for fuel $\left(\mathrm{H}_{2} \& \mathrm{CO}\right)$ and electricity cogeneration in DC-SOFC with in situ catalytic steam-carbon gasification.

\section{Conclusion}

Both experimental testing and mathematical modeling are conducted to study the performance of DC-SOFCs with in situ catalytic gasification of carbon by $\mathrm{H}_{2} \mathrm{O}$. The model is compared and validated by experimental results. Parametric analyses are carried out to investigate the effects of operating potential, anode inlet gas flowrate and operating temperature on the performance of the cell. The performance of DC-SOFCs with and without catalyst are also compared to evaluate the improvement by adding catalyst for steam-carbon gasification in DC-SOFCs.

In situ catalytic steam-carbon gasification largely increases the gas fuel production rate for 
electrochemical reaction, which brings a significant improvement of output power density. A peak power density of about $4600 \mathrm{~W} \mathrm{~m}^{-2}$ is obtained with the help of catalyst compared with that of $3000 \mathrm{~W} \mathrm{~m}^{-2}$ without catalyst. The high fuel percentage in anode outlet gas is also obtained due to the faster gasification reaction with catalyst. It is found that the mole fraction of $\mathrm{H}_{2}$ and $\mathrm{CO}$ in the outlet gas is significantly affected by the inlet gas flow rate. The mole fraction of $\mathrm{CO}$ is larger than $\mathrm{H}_{2}$ at small inlet gas flow rate $(<100 \mathrm{SCCM})$, while $\mathrm{H}_{2}$ exceeds $\mathrm{CO}$ at high inlet gas flow rate ( $>100 \mathrm{SCCM})$. Thus, it could be possible to adjust the fuel component by controlling the inlet gas flow rate. The operating temperature also significantly affect the fuel percentage in outlet gas, where a high fuel percentage ( $84 \%$ at $1173 \mathrm{~K})$ can be obtained, indicating the possibility for fuel and electricity co-generation in DC-SOFC with $\mathrm{H}_{2} \mathrm{O}$ as agent by integrating in situ catalytic steam-carbon gasification.

\section{Acknowledgement}

This research is supported by a grant (PolyU 152127/14E) from Research Grant Council, University Grants Committee, Hong Kong SAR, a grant from Environment and Conservation Fund (ECF 54/2015), Hong Kong SAR, and a grant from Research Institute for Sustainable Urban Development (RISUD) (1-ZVEA).

We gratefully acknowledge the financial support of the National Science Foundation of China (Grant No. 51406091).

\section{Nomenclature}

Abbreviation

DC-SOFC Direct-carbon solid oxide fuel cell

LSCF Lanthanum strontium cobalt ferrite

SCCM Standard cubic centime per minute 
SDC

SOFC

TPB

WGSR

YSZ

Roman

$B_{0}$

$\mathrm{C}_{\mathrm{CO}_{2}}$

$\mathrm{C}_{\mathrm{H}_{2} \mathrm{O}}$

$D_{i}^{e f f}$

$D_{i k}^{e f f}$

$D_{\text {im }}^{\text {eff }}$

$E_{\text {act }}$

$E_{C O}$

$E_{C O}^{0}$

$E_{e q}$

$E_{\mathrm{H}_{2}}$

$E_{\mathrm{H}_{2}}^{0}$

F

$i_{o}$

$\mathrm{n}$

$N_{i}$

$p$

$R$

$R_{C_{-} \mathrm{CO} 2}$

$R_{C_{-} \mathrm{H} 2 \mathrm{O}}$

$R_{W G S R}$

$\mathrm{T}$

$\mathrm{u}$

$\mathrm{V}$

$y_{i}$

Greek letters
Samaria-doped ceria

Solid oxide fuel cell

Triple phase boundary

Water gas shift reaction

Yttrium stabilized zirconium

Permeability coefficient, $\mathrm{m}^{2}$

Mole concentration of carbon dioxide, $\mathrm{mol} \cdot \mathrm{m}^{-3}$

Mole concentration of water, $\mathrm{mol} \cdot \mathrm{m}^{-3}$

Effective diffusivity of species $i, \mathrm{~m}^{2} \cdot \mathrm{s}^{-1}$

Knudsen diffusion coefficient of $i, \mathrm{~m}^{2} \cdot \mathrm{s}^{-1}$

Molecular diffusion coefficient of $i, \mathrm{~m}^{2} \cdot \mathrm{s}^{-1}$

Activation energy, $\mathrm{J} \cdot \mathrm{mol}^{-1}$

Equilibrium potential for carbon monoxide oxidization, $\mathrm{V}$

Standard equilibrium potential for carbon monoxide oxidization, $\mathrm{V}$

Equilibrium Nernst potential, $\mathrm{V}$

Equilibrium potential for hydrogen oxidization, $\mathrm{V}$

Standard equilibrium potential for hydrogen oxidization, $\mathrm{V}$

Faraday constant, $96485 \mathrm{C} \cdot \mathrm{mol}^{-1}$

Exchange current density, $\mathrm{A} \cdot \mathrm{m}^{-2}$

Number of electrons transferred per electrochemical reaction

Flux of mass transport, $\mathrm{kg} \cdot \mathrm{m}^{-3} \cdot \mathrm{s}^{-1}$

(partial) Pressure, $\mathrm{Pa}$

Gas constant, $8.314 \mathrm{~J} \cdot \mathrm{mol}^{-1} \cdot \mathrm{K}^{-1}$

Reaction rate of Boudouard reaction, $\mathrm{mol} \cdot \mathrm{m}^{-3} \cdot \mathrm{s}^{-1}$

Reaction rate of steam-carbon gasification, $\mathrm{mol} \cdot \mathrm{m}^{-3} \cdot \mathrm{s}^{-1}$

Reaction rate of water gas shift reaction, $\mathrm{mol} \cdot \mathrm{m}^{-3} \cdot \mathrm{s}^{-1}$

Temperature, $\mathrm{K}$

Velocity field, $\mathrm{m}^{3} \cdot \mathrm{s}^{-1}$

Volume fraction

Mole fraction of component $i$ 
$\varepsilon$

$\eta_{\text {act }}$

$\eta_{\text {ohmic }}$

$\kappa$

$\mu$

$\rho$

$\sigma$

$\gamma$

$\tau$

$\emptyset$

Subscripts

an

ca
Charge transfer coefficient

Electrochemical kinetics parameter for $\mathrm{H}_{2}$

Porosity

Activation polarization, $\mathrm{V}$

Ohmic polarization, $\mathrm{V}$

Permeability, $\mathrm{m}^{2}$

Dynamic viscosity of fluid, $\mathrm{Pa} \cdot \mathrm{s}$

Fluid density, $\mathrm{kg} \cdot \mathrm{m}^{-3}$

Conductivity, S/m

Pre-exponential factor, $\mathrm{A} \mathrm{m}^{-2}$

Tortuosity

Potential, V 


$\begin{array}{ll}\text { co } & \text { Carbon monoxide } \\ \mathrm{H}_{2} & \text { Hydrogen } \\ 1 & \text { Ionic phase } \\ \mathrm{s} & \text { Electronic phase } \\ \text { Superscripts } & \\ 0 & \text { Parameter at equilibrium conditions } \\ \text { eff } & \text { Effective } \\ \text { L } & \text { Local }\end{array}$

\section{Reference}

[1] Park S, Vohs JM, Gorte RJ. Direct oxidation of hydrocarbons in a solid-oxide fuel cell. Nature. 2000;404:265-7.

[2] Shao ZP, Haile SM. A high performance cathode for the next generation of solid oxide fuel cells, Nature. 2004; 431: 170-173.

[3] Ruiz-Morales JC, Canales Vazquez J, Savaniu CD, Marrero-Lopez D, Zhou W, Irvine JTS, Disruption of extended defects in solid oxide fuel cell anodes for methane oxidation. Nature. 2006; 439: 568-571.

[4] Wachsman ED, Lee KT, Lowering the temperature of solid oxide fuel cells. Science. 2011; 334(6058): 935-939.

[5] Ni M, Modeling of solid oxide fuel cells. Science Bulletin. 2016. 61(17): 1311-1312.

[6] Cai WZ, Liu J, Yu FY, Zhou Q, Zhang YP, Wang XQ, Liu ML, Ni M. A high performance direct carbon solid oxide fuel cell fueled by Ca-loaded activated carbon. International Journal of Hydrogen Energy. 2017;42(33):21167-21176.

[7] Giddey S, Badwal SPS, Kulkarni A, Munnings C. A comprehensive review of direct carbon fuel cell technology. Progress in Energy and Combustion Science. 2012;38:360-99. 
[8] Gür TM. Critical Review of Carbon Conversion in "Carbon Fuel Cells". Chemical Reviews. 2013;113:6179-206.

[9] Jiang CR, Ma JJ, Corre G, Jain SL, Irvine JTS. Challenges in developing direct carbon fuel cells. Chemical Society Reviews. 2017; 46: 2889-2912.

[10] Wu Y, Su C, Zhang C, Ran R, Shao Z. A new carbon fuel cell with high power output by integrating with in situ catalytic reverse Boudouard reaction. Electrochemistry Communications. 2009; 11:1265-8.

[11] Tang Y, Liu J. Effect of anode and Boudouard reaction catalysts on the performance of direct carbon solid oxide fuel cells. International Journal of Hydrogen Energy. 2010;35:1118893.

[12] Li C, Shi Y, Cai N. Performance improvement of direct carbon fuel cell by introducing catalytic gasification process. Journal of Power Sources. 2010;195:4660-6.

[13] Cantero-Tubilla B, Xu C, Zondlo JW, Sabolsky K, Sabolsky EM. Investigation of anode configurations and fuel mixtures on the performance of direct carbon fuel cells (DCFCs). Journal of Power Sources. 2013;238:227-35.

[14] Jiao Y, Zhao J, An W, Zhang L, Sha Y, Yang G, et al. Structurally modified coal char as a fuel for solid oxide-based carbon fuel cells with improved performance. Journal of Power Sources. 2015;288:106-14.

[15] Ong KM, Ghoniem AF. Modeling of indirect carbon fuel cell systems with steam and dry gasification. Journal of Power Sources. 2016;313:51-64.

[16] Xu H, Chen B, Zhang H, Sun Q, Yang G, Ni M. Modeling of direct carbon solid oxide fuel cells with $\mathrm{H} 2 \mathrm{O}$ and $\mathrm{CO} 2$ as gasification agents. International Journal of Hydrogen Energy. 2017;42:15641-51.

[17] Kopyscinski J, Lam J, Mims CA, Hill JM. K2CO3 catalyzed steam gasification of ashfree coal. Studying the effect of temperature on carbon conversion and gas production rate using a drop-down reactor. Fuel. 2014;128:210-9.

[18] Shi Y, Cai N, Li C, Bao C, Croiset E, Qian J, et al. Modeling of an anode-supported NiYSZ|Ni-ScSZ|ScSZ|LSM-ScSZ multiple layers SOFC cell: Part I. Experiments, model development and validation. Journal of Power Sources. 2007;172:235-45.

[19] Luo Y, Shi YX, Li WY, Ni M, Cai NS, Elementary reaction modeling and experimental characterization of solid oxide fuel-assisted steam electrolysis cells. International Journal of Hydrogen Energy. 2014. 39(20): 10359-10373.

[20] Eguchi K. Ceramic materials containing rare earth oxides for solid oxide fuel cell. J Alloy Compd. 1997;250:486-91.

[21] Fan B, Yan J, Yan X. The ionic conductivity, thermal expansion behavior, and chemical compatibility of La0.54Sr0.44Co0.2Fe $0.8 \mathrm{O} 3-\delta$ as SOFC cathode material. Solid State Sciences. 2011;13:1835-9.

[22] Tai LW, Nasrallah MM, Anderson HU, Sparlin DM, Sehlin SR. Structure and electrical properties of La1 - xSrxCo1 - yFeyO3. Part 2. The system La1 - xSrxCo0.2Fe0.8O3. Solid State Ionics. 1995;76:273-83.

[23] Huang Z, Zhang J, Zhao Y, Zhang H, Yue G, Suda T, et al. Kinetic studies of char gasification by steam and $\mathrm{CO} 2$ in the presence of $\mathrm{H} 2$ and $\mathrm{CO}$. Fuel Processing Technology. 2010;91:843-7.

[24] Ni M. Modeling of SOFC running on partially pre-reformed gas mixture. International Journal of Hydrogen Energy. 2012;37:1731-45.

[25] Xu H, Chen B, Liu J, Ni M. Modeling of direct carbon solid oxide fuel cell for CO and electricity cogeneration. Applied Energy. 2016;178:353-62.

[26] Xu H, Chen B, Ni M. Modeling of Direct Carbon-Assisted Solid Oxide Electrolysis Cell 
(SOEC) for Syngas Production at Two Different Electrodes. Journal of The Electrochemical Society. 2016;163:F3029-F35.

[27] $\mathrm{Xu} \mathrm{H}$, Chen B, Irvine J, Ni M. Modeling of CH4-assisted SOEC for $\mathrm{H} 2 \mathrm{O} / \mathrm{CO} 2$ coelectrolysis. International Journal of Hydrogen Energy. 2016;41:21839-49.

[28] Chen B, Xu HR, NI M, Modelling of finger-like channelled anode support for SOFCs application, Science Bulletin. 2016; 61(17): 1324-1332.

[29] Suwanwarangkul R, Croiset E, Fowler MW, Douglas PL, Entchev E, Douglas MA. Performance comparison of Fick's, dusty-gas and Stefan-Maxwell models to predict the concentration overpotential of a SOFC anode. Journal of Power Sources. 2003;122:9-18. [30] Ni M, An electrochemical model for syngas production by co-electrolysis of $\mathrm{H}_{2} \mathrm{O}$ and $\mathrm{CO}_{2}$. Journal of Power Sources. 2012; 202: 209-216.

[31] Todd B, Young JB. Thermodynamic and transport properties of gases for use in solid oxide fuel cell modelling. Journal of Power Sources. 2002;110:186-200. 


\section{List of Tables}

Table 1 Material properties

Table 2 Reaction parameters

Table 3 Operation parameters for operating potential effect study in DC-SOFCs

Table 4 Operation parameters for anode inlet gas flow rate effect study in DC-SOFCs

Table 5 Operation parameters for temperature effect study in DC-SOFCs 
Table 1 Material properties [18-22]

\begin{tabular}{|c|c|c|}
\hline Parameters & Value or expression & Unit \\
\hline \multicolumn{3}{|l|}{ Ionic conductivity } \\
\hline YSZ & $3.34 \times 10^{4} e^{\frac{-10300}{T}}$ & $\mathrm{Sm}^{-1}$ \\
\hline SDC & $\frac{100}{T} \times 10^{5.48077-\frac{3792.53}{T}}$ & $\mathrm{Sm}^{-1}$ \\
\hline LSCF & $\frac{100}{T} \times 10^{2.51289-\frac{3036.75}{T}}$ & $\mathrm{Sm}^{-1}$ \\
\hline \multicolumn{3}{|c|}{ Electronic conductivity } \\
\hline LSCF & $\frac{100}{T} \times 10^{4.32576+\frac{1204.26}{T}}$ & $\mathrm{Sm}^{-1}$ \\
\hline $\mathbf{N i}$ & $3.27 \times 10^{6}-1065.3 T$ & $\mathrm{Sm}^{-1}$ \\
\hline \multicolumn{3}{|l|}{ Porosity } \\
\hline Cathode & 0.2 & \\
\hline Anode & 0.6 & \\
\hline \multicolumn{3}{|c|}{ Anode volume fraction } \\
\hline YSZ & 0.4 & \\
\hline $\mathbf{N i}$ & 0.6 & \\
\hline \multicolumn{3}{|l|}{$\mathbf{S}_{\mathrm{TPB}}$} \\
\hline Cathode layer & $2.14 \times 10^{5}$ & $\mathrm{~m}^{2} \mathrm{~m}^{-3}$ \\
\hline Anode layer & $2.14 \times 10^{5}$ & $\mathrm{~m}^{2} \mathrm{~m}^{-3}$ \\
\hline Electrode tortuosity & 3 & \\
\hline Solid carbon & \multicolumn{2}{|c|}{ Activated carbon (Aladdin, Shanghai, China; A. R.) } \\
\hline
\end{tabular}


Table 2 Reaction parameters

\begin{tabular}{|l|l|l|}
\hline Parameter & Value & Unit \\
\hline Chemical reaction without catalyst & & \\
\hline$K_{1}$ & $1.03 \times 10^{-3}$ & $\mathrm{~s} \mathrm{~mol} \mathrm{~kg}^{-1} \mathrm{~m}^{-2}$ \\
\hline$K_{2}$ & $9.88 \times 10^{-4}$ & $\mathrm{~Pa}^{-1}$ \\
\hline$K_{3}$ & $8.13 \times 10^{-5}$ & $\mathrm{~Pa}^{-1}$ \\
\hline$K_{4}$ & $3.11 \times 10^{-5}$ & $\mathrm{~s} \mathrm{~mol} \mathrm{~kg}^{-1} \mathrm{~m}^{-2}$ \\
\hline$K_{5}$ & $1.25 \times 10^{-3}$ & $\mathrm{~Pa}^{-1}$ \\
\hline$K_{6}$ & $3.82 \times 10^{-5}$ & $\mathrm{~Pa}^{-1}$ \\
\hline Chemical reaction with catalyst & & \\
\hline$K_{1}$ & $3.87 \times 10^{-2}$ & $\mathrm{~s} \mathrm{~mol} \mathrm{~kg}^{-1} \mathrm{~m}^{-2}$ \\
\hline$K_{2}$ & $9.88 \times 10^{-4}$ & $\mathrm{~Pa}^{-1}$ \\
\hline$K_{3}$ & $8.13 \times 10^{-5}$ & $\mathrm{~Pa}^{-1}$ \\
\hline$K_{4}$ & $1.17 \times 10^{-3}$ & $\mathrm{~s} \mathrm{~mol} \mathrm{~kg}^{-1} \mathrm{~m}^{-2}$ \\
\hline$K_{5}$ & $1.25 \times 10^{-3}$ & $\mathrm{~Pa}^{-1}$ \\
\hline$K_{6}$ & $3.82 \times 10^{-5}$ & $\mathrm{~Pa}^{-1}$ \\
\hline Electrochemical reaction & $3.48 \times 10^{9}$ & $\mathrm{~A} \mathrm{~m}^{-2}$ \\
\hline$\gamma_{H_{2}}$ & & \\
\hline$E_{a c t, H_{2}}$ & & $\mathrm{~J} \mathrm{~mol}^{-1}$ \\
\hline$\gamma_{O_{2}}$ & & \\
\hline
\end{tabular}




\begin{tabular}{|l|l|l|}
\hline$E_{a c t, O_{2}}$ & $1.2 \times 10^{5}$ & $\mathrm{~J} \mathrm{~mol}^{-1}$ \\
\hline$\gamma_{C O}$ & $1.67 \times 10^{9}$ & $\mathrm{~A} \mathrm{~m}^{-2}$ \\
\hline$E_{a c t, C O}$ & $1.2 \times 10^{5}$ & $\mathrm{~J} \mathrm{~mol}^{-1}$ \\
\hline$\alpha_{H_{2}}$ & 0.5 & \\
\hline$\alpha_{C O}$ & 0.5 & \\
\hline$\alpha_{O_{2}}$ & 0.85 & \\
\hline
\end{tabular}


Table 3 Operation parameters for operating potential effect study in DC-SOFCs

\begin{tabular}{|l|l|l|}
\hline Parameter & Value & Unit \\
\hline Operating potential & $0-1$ & V \\
\hline Anode inlet gas flow rate & 90 & SCCM \\
\hline Cathode inlet gas flow rate & 10 & SCCM \\
\hline Anode gas composition & $\mathrm{H}_{2} \mathrm{O}$ & \\
\hline Cathode gas composition & $\mathrm{Air}$ & $\mathrm{K}$ \\
\hline Temperature & 1123 & \\
\hline
\end{tabular}

Table 4 Operation parameters for anode inlet gas flow rate effect study in DC-SOFCs

\begin{tabular}{|l|l|l|}
\hline Parameter & Value & Unit \\
\hline Operating potential & 0.5 & $\mathrm{~V}$ \\
\hline Anode inlet gas flow rate & $1-200$ & SCCM \\
\hline Cathode inlet gas flow rate & 10 & SCCM \\
\hline Anode gas composition & $\mathrm{H}_{2} \mathrm{O}$ & \\
\hline Cathode gas composition & $\mathrm{Air}$ & $\mathrm{K}$ \\
\hline Temperature & 1123 & \\
\hline
\end{tabular}


Table 5 Operation parameters for temperature effect study in DC-SOFCs

\begin{tabular}{|l|l|l|}
\hline Parameter & Value & Unit \\
\hline Operating potential & 0.5 & V \\
\hline Anode inlet gas flow rate & 90 & SCCM \\
\hline Cathode inlet gas flow rate & 10 & SCCM \\
\hline Anode gas composition & $\mathrm{H}_{2} \mathrm{O}$ & \\
\hline Cathode gas composition & Air & K \\
\hline Temperature & $923-1173$ & \\
\hline
\end{tabular}




\section{List of Figures}

Fig.1. Schematic of DC-SOFC using $\mathrm{H}_{2} \mathrm{O}$ as gasification agent

Fig.2 Model validation for DC-SOFCs using $\mathrm{H}_{2} \mathrm{O}$ as agents without (a) and with (b) catalyst

Fig. 3 The voltage-current density-power density relationships of DC-SOFCs using $\mathrm{H}_{2} \mathrm{O}$ as agents with and without catalyst

Fig. 4 The carbon gasification rate $\left(\mathrm{mol} \mathrm{m}^{-3} \mathrm{~s}^{-1}\right)$ without (a) with (b) catalyst in carbon layer and mole fraction of fuel without (c) and with (d) catalyst in anode of DC-SOFCs at $0.8 \mathrm{~V}$ and $1123 \mathrm{~K}$

Fig. 5 Distribution change of $\mathrm{H}_{2}$ mole fraction in anode with catalytic gasification at $0.9 \mathrm{~V}$ and $0.1 \mathrm{~V}$ operating potentials and $1123 \mathrm{~K}$.

Fig. 6 The effect of anode inlet gas flow rate on current density of DC-SOFCs with $\mathrm{H}_{2} \mathrm{O}$ as agents at $0.5 \mathrm{~V}$ and $1123 \mathrm{~K}$

Fig. 7 The effect of anode inlet gas flow rate on fuel mole fraction (a) and chemical reaction rates (b) in anode surface of DC-SOFCs at $0.5 \mathrm{~V}$ and $1123 \mathrm{~K}$

Fig. 8 The effect of operating temperature on current density (a) and fuel percentage in outlet gas (b) of DC-SOFCs with $\mathrm{H}_{2} \mathrm{O}$ as agents at $0.5 \mathrm{~V}$ operating potential 


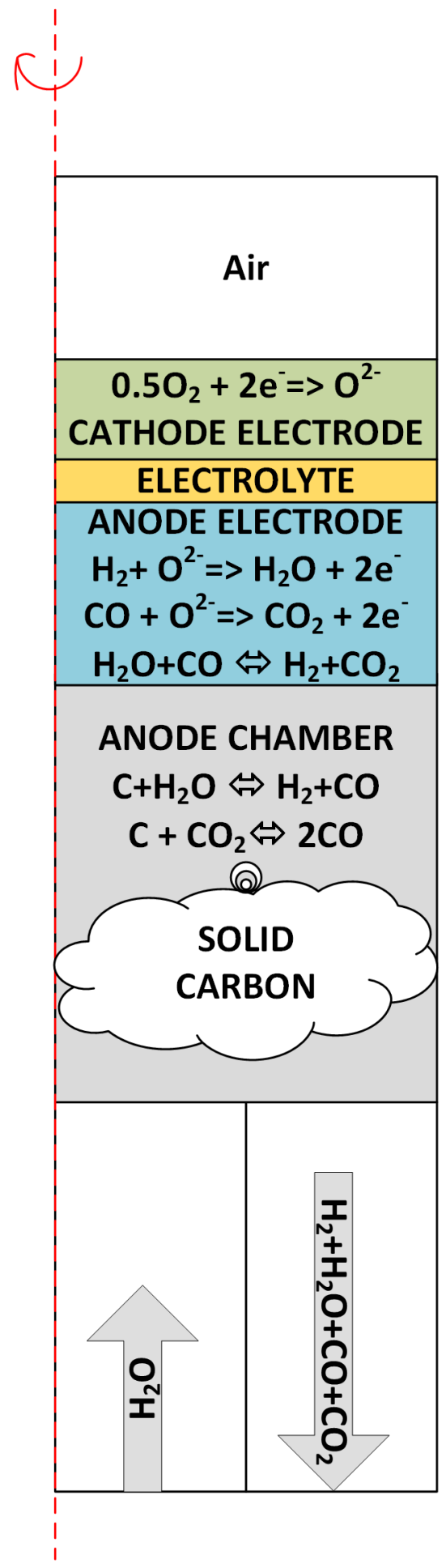

Fig.1. Schematic of DC-SOFC using $\mathrm{H}_{2} \mathrm{O}$ as gasification agent. 

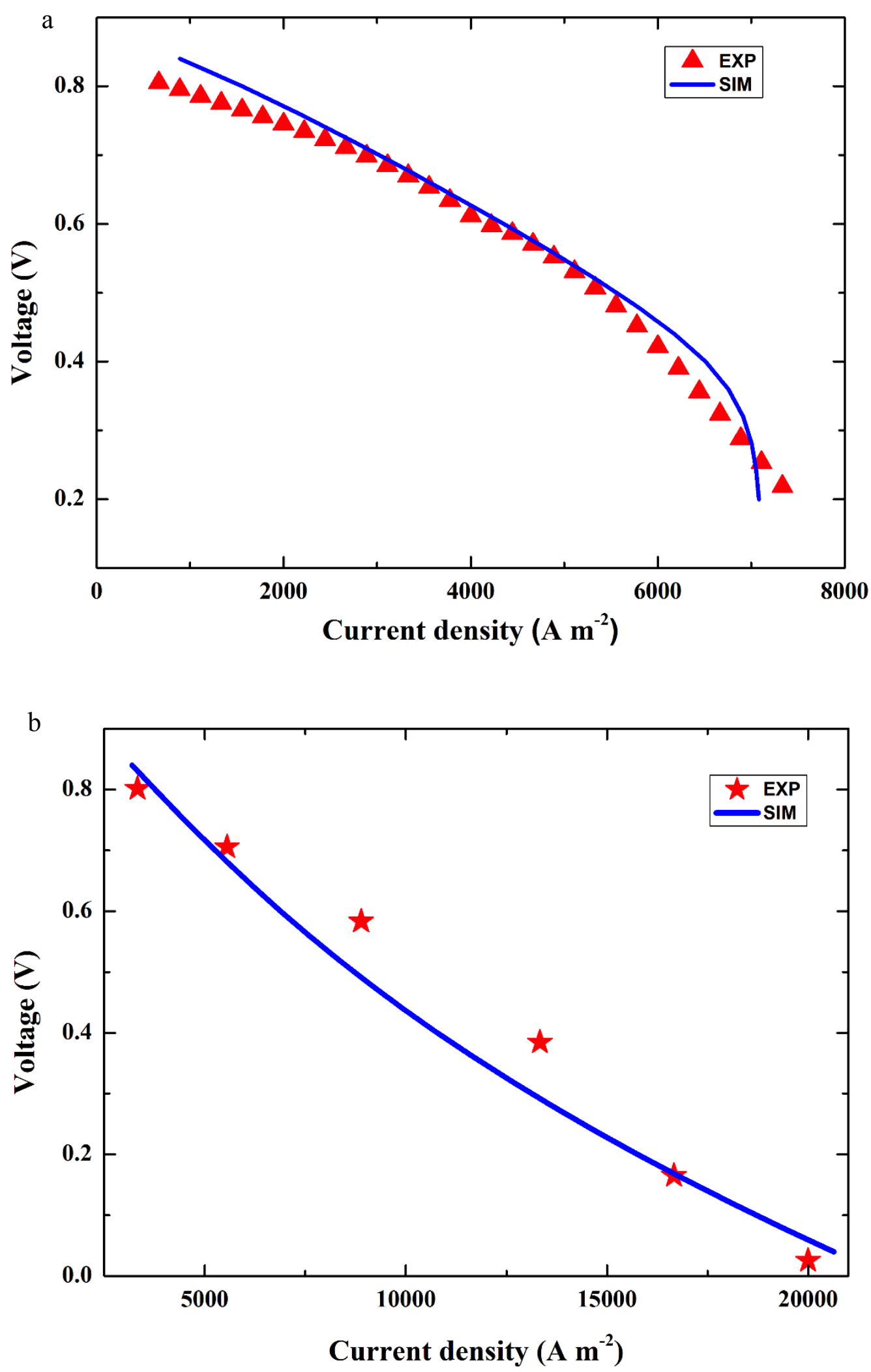

Fig.2 Model validation for DC-SOFCs using $\mathrm{H}_{2} \mathrm{O}$ as agents without (a) and with (b) catalyst. 


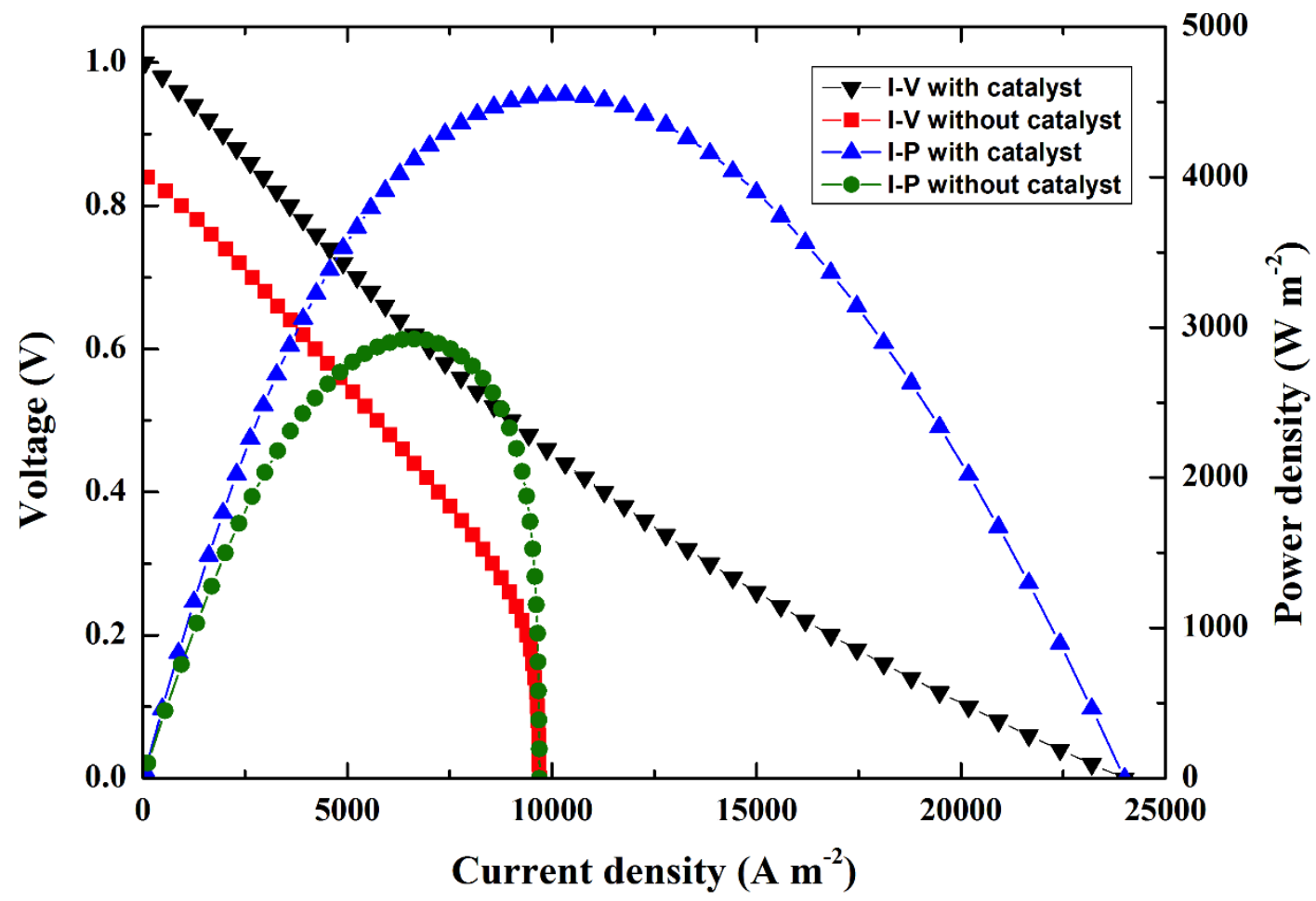

Fig. 3 The voltage-current density-power density relationships of DC-SOFCs using $\mathrm{H}_{2} \mathrm{O}$ as agents with and without catalyst. 

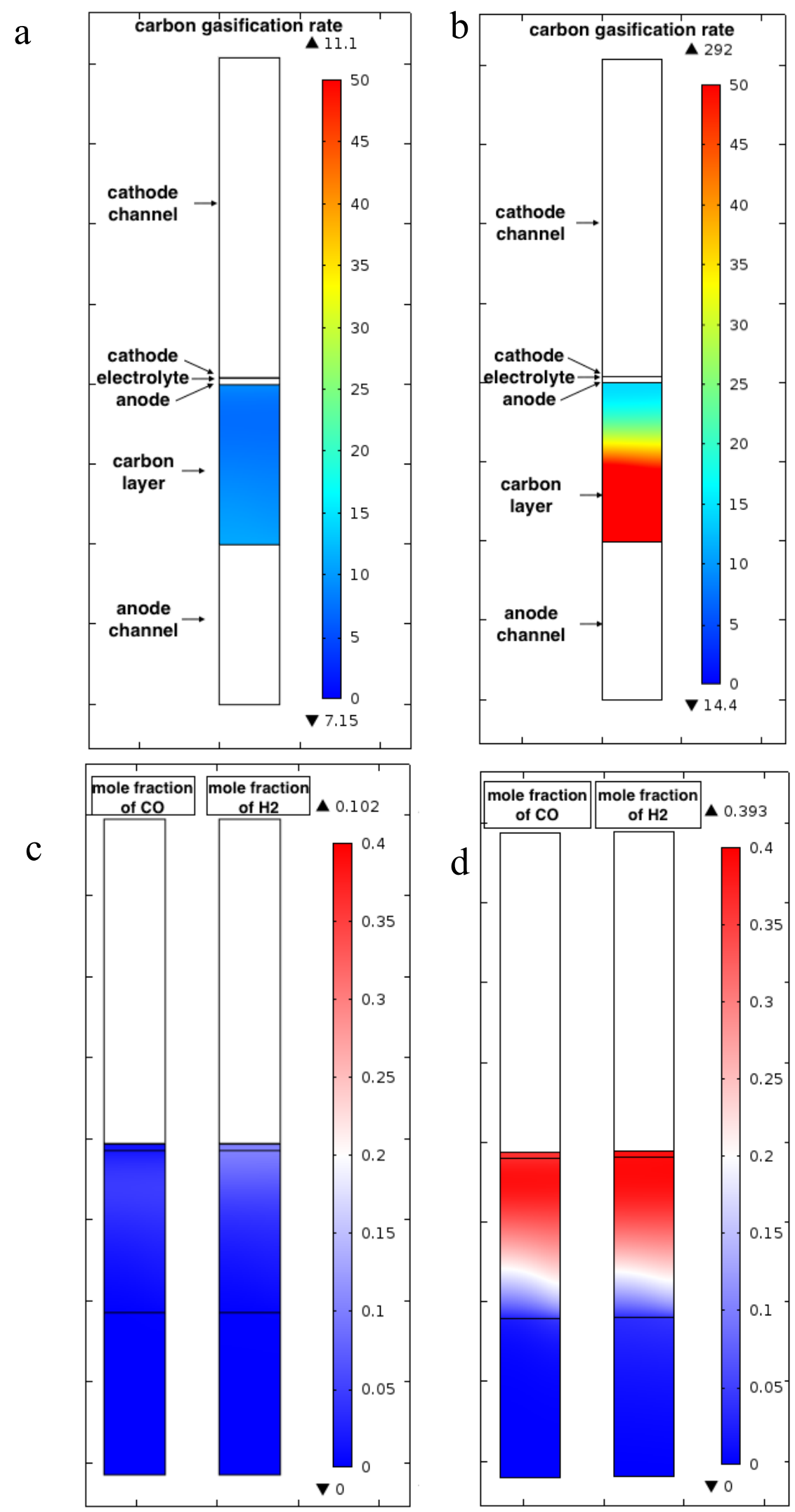

Fig. 4 The carbon gasification rate $\left(\mathrm{mol} \mathrm{m}^{-3} \mathrm{~s}^{-1}\right)$ without (a) with (b) catalyst in carbon layer and mole fraction of fuel without $(\mathrm{c})$ and with $(\mathrm{d})$ catalyst in anode of DC-SOFCs at $0.8 \mathrm{~V}$ and $1123 \mathrm{~K}$ 

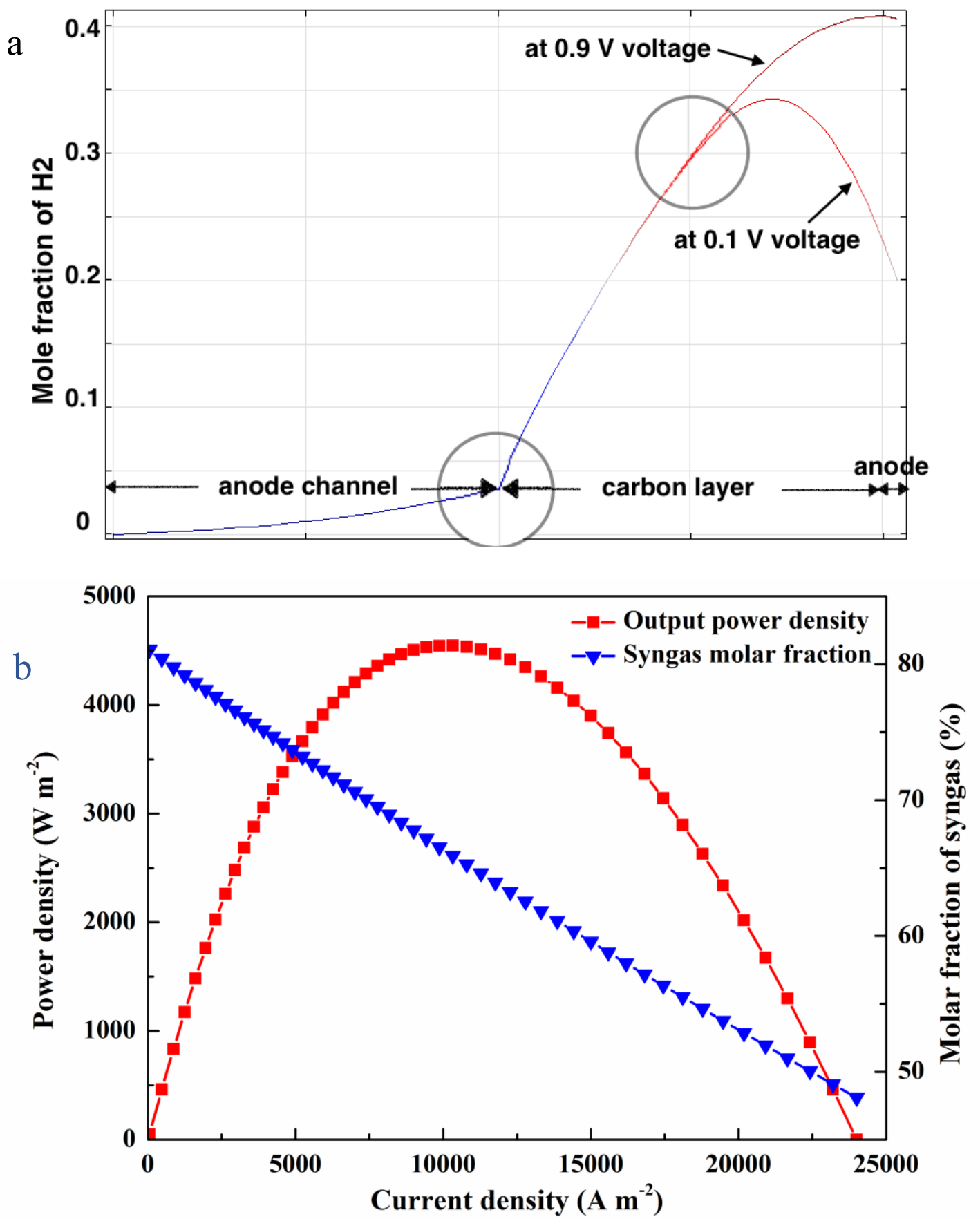

Fig. 5 (a)Distribution change of $\mathrm{H}_{2}$ mole fraction in anode with catalytic gasification at $0.9 \mathrm{~V}$ and $0.1 \mathrm{~V}$ operating potentials and $1123 \mathrm{~K}$; (b) I-P characteristics and syngas molar fraction change at different operating current densities. 


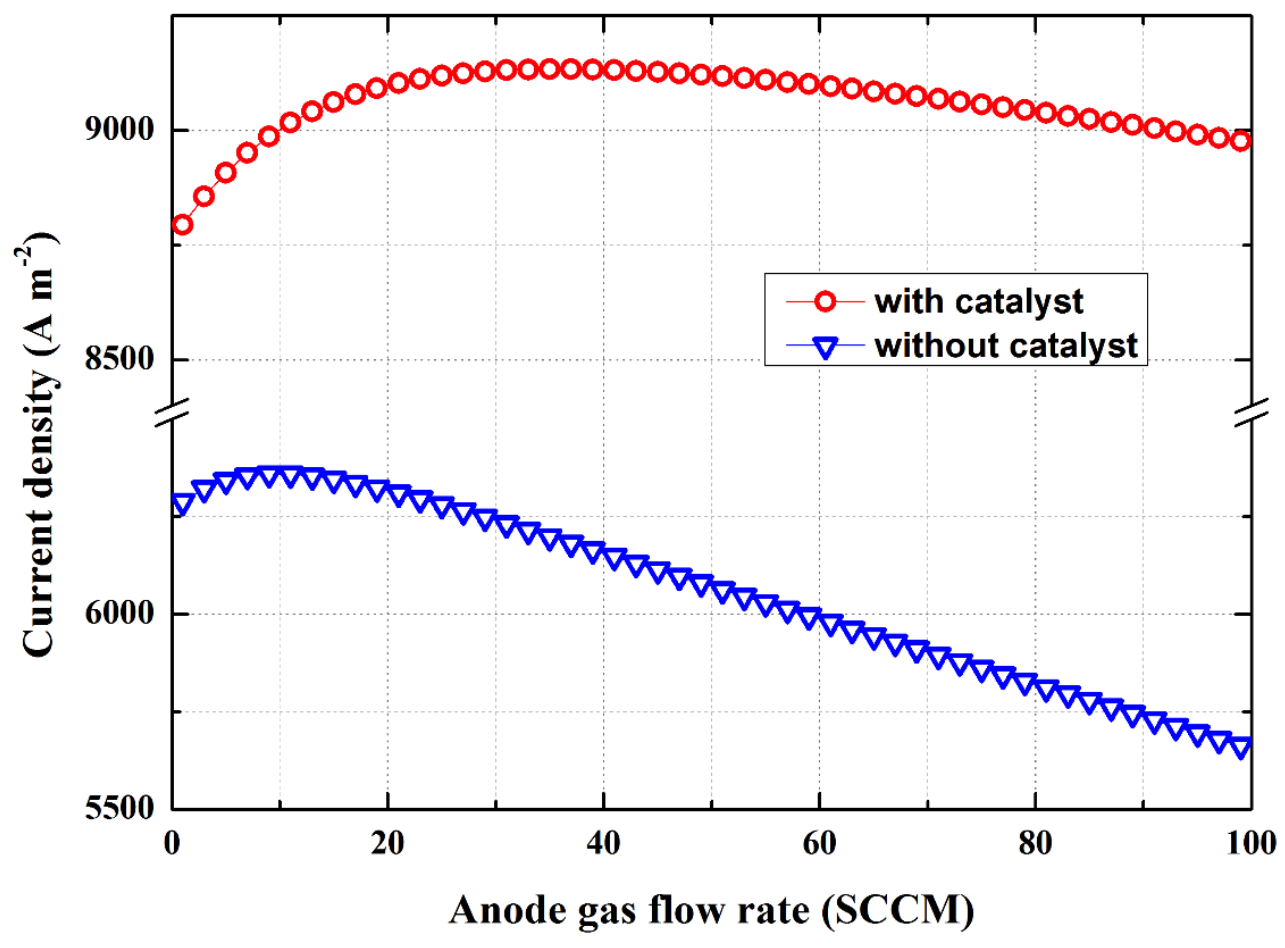

Fig. 6 The effect of anode inlet gas flow rate on current density of DC-SOFCs with $\mathrm{H}_{2} \mathrm{O}$ as agents at $0.5 \mathrm{~V}$ and $1123 \mathrm{~K}$ 

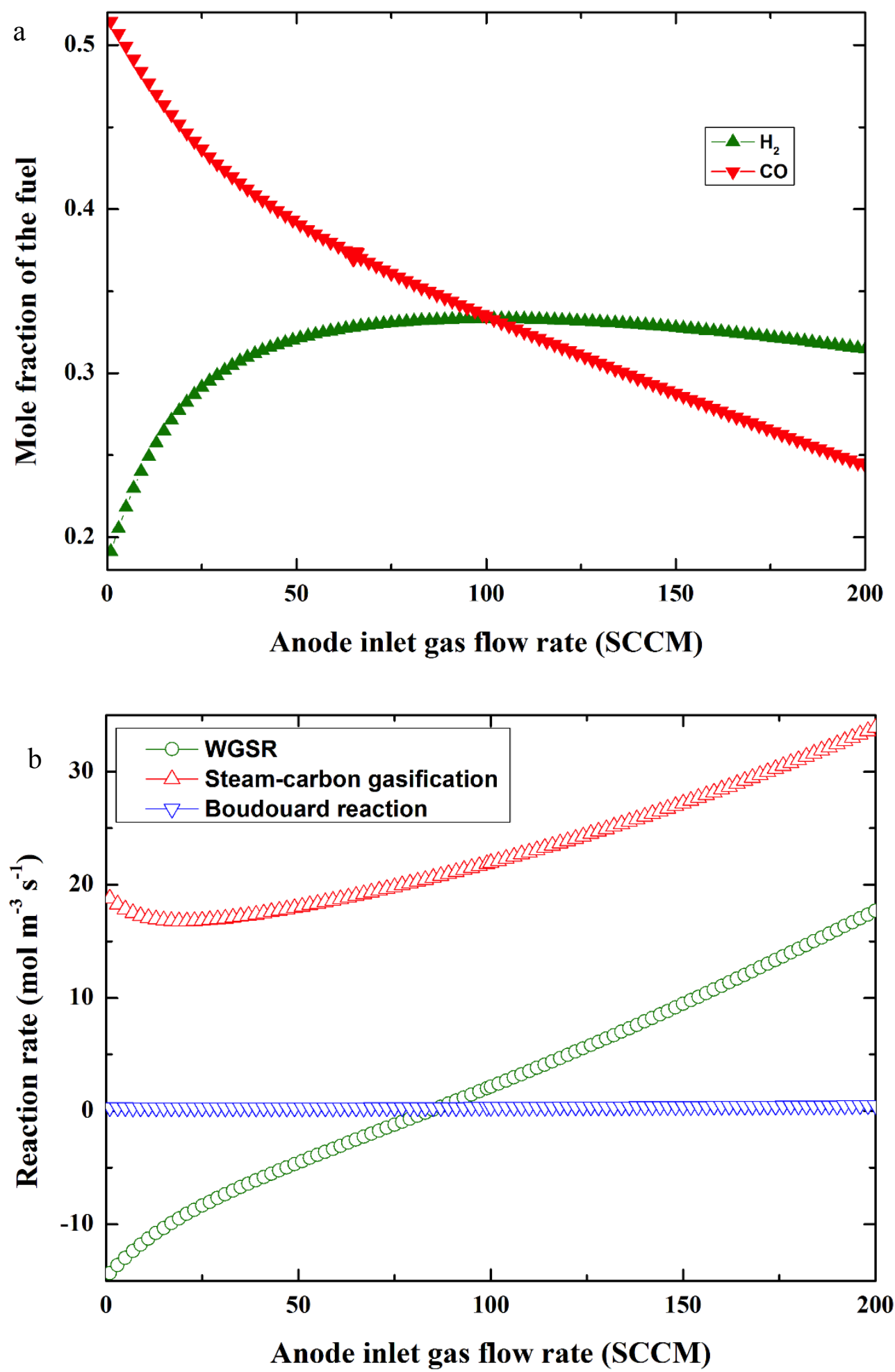

Fig. 7 The effect of anode inlet gas flow rate on fuel mole fraction (a) and chemical reaction rates (b) in anode surface of DC-SOFCs at $0.5 \mathrm{~V}$ and $1123 \mathrm{~K}$ 

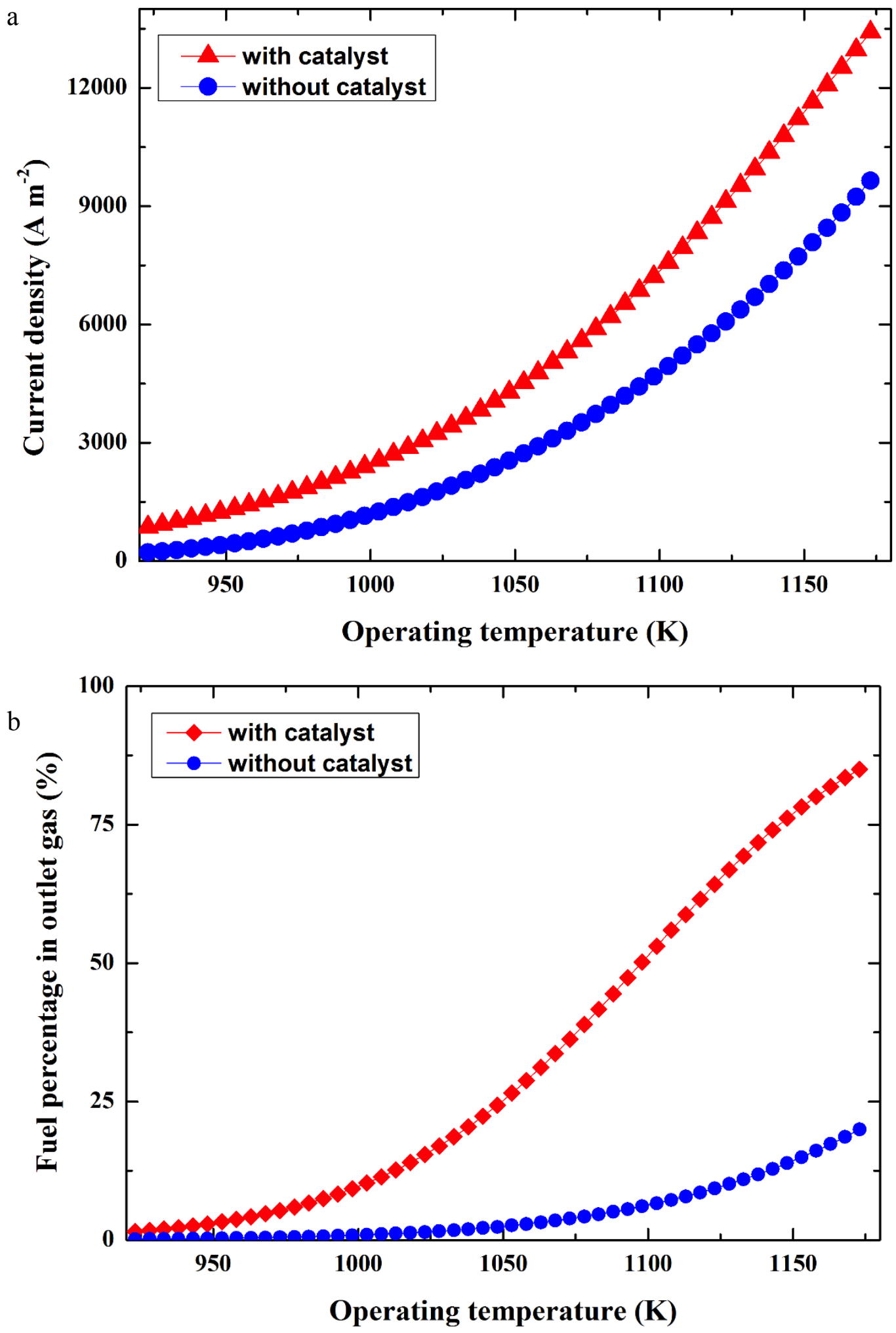

Fig.8 The effect of operating temperature on current density (a) and fuel percentage in outlet gas (b) of DC-SOFCs with $\mathrm{H}_{2} \mathrm{O}$ as agents at $0.5 \mathrm{~V}$ operating potential 